\title{
On Demands of Tourism Market and Talents Cultivation in Higher Tourism Education
}

\author{
He Jianbo \\ School of Tourism \\ Jiangxi Science \& Technology Normal University \\ Nanchang, China
}

\author{
Wang Zhen \\ School of Foreign Languages \\ Jiangxi Science \& Technology Normal University \\ Nanchang, China
}

\begin{abstract}
In China, tourism industry has been developing rapidly in recent years. Meanwhile, the blooming tourism industry still faces lots of problems, such as extreme shortage of tourism professionals, imbalance of tourism structure and so on. In fact, low entry rate and high turnover rate are two serious problems exist in obtaining employment in tourism industry of tourism major graduates. The fundamental reason for this is the gap between higher tourism education and demands of tourism market. This article puts forward some new thoughts in terms of reforming the training mode of tourism professionals, improving the construction of teaching staff and innovating course system in higher tourism education, etc.
\end{abstract}

Keywords-tourism industry; market demands; tourism professionals; tourism structure; course system

\section{INTRODUCTION}

Tourism in our country has sprung up exuberantly since the late 1970s. And after more than 3 decades' development, the scale of tourism nowadays reaches to 2 billion per year. The revenue achieves 1.29 trillion $\mathrm{RMB}$, and the added value of tourism accounts for over 4\% of GDP (gross domestic product) and tourism industry has become a very important part of GNP (gross national product). With the expansion of tourism market, the overall demand for tourism professionals is increasingly greater. However, at present, Chinese tourism industry is facing the extreme shortage of professionals, the imbalance of tourism structure and many other problems.

The development of tourism industry and the demand of tourism market are changing rapidly, while the tourism talent development has been a bottleneck restricting the scientific development of tourism industry in our country. From the aspect of tourism education, colleges should develop effective training programs and teaching programs according to the specific needs of the market for talents, cultivate applied talents with high professional skills, integrate social needs with talent development and achieve development and reform of higher vocational education in tourism.

Under such development trend, the contradiction between the booming tourism demand for tourism talents and the shortage of high-quality talents has become increasingly prominent. China's tourism talents cultivation has appeared lots of problems like insufficient quantity, low quality, imbalanced structure, the dislocation between tourism talent training and market demand, causing the graduate employment appears the employment structural contradiction of "low employment degree", "high attrition rate", and so on. Thus, the reality of tourism talents cultivation is very not optimistic. The key to solve these problems lies in optimizing the talent training of tourism higher education, aiming at the market demands and meeting the actual employment demands of tourism enterprises After investigation, it is found that there is no positive ratio between the competitiveness of students majoring in tourism management and the booming tourism industry. On the one hand, tourism management graduates are unfit for a higher post but unwilling to take a lower one in their work, which is not in line with employment requirements. Enterprises spend a lot of money on the education and training of employees. On the other hand, tourism management graduates working in tourism enterprises will feel uncomfortable after a period of time, thinking that jobs cannot reflect their knowledge, also cannot achieve their goals and life value, so they will choose to switch to other business units or cross-industry, resulting in very high Job hopping rate in tourism industry. According to China education online, only $19.05 \%$ of graduates from tourism colleges and universities are still engaged in tourism industry after graduation. After two years of working, only $80 \%$ of the graduates of tourism management major will still stay in tourism industry, and the hopping rate reaches $20 \%$, which is far higher than the normal hopping rate of an industry. This reflects a serious mismatch between the talents cultivated by tourism education and the demand of tourism market.

\section{The STATUS Quo of TALENTS DEMAND IN ChINA’S TOURISM INDUSTRY}

In the face of exponentially growing rate in tourism market, the demand for tourism professionals rises year after year. According to preliminary estimates, the current national tourism industry employers are about 7 million, while the actual needs of tourism professionals are more than 9 million, which means the talent gap in the tourism industry is at least 2 million. In the future, this gap will increase progressively at a rate of 200 thousands per year. Among them, the demand for senior management professionals in tourism industry will reach about 70 thousand people, while there are only 30 thousand people at present; The requirement of tour guides are about 300 thousands, while the current number of them is about 200 thousands, and there's a gap of 100 thousands tour guides. Some investigators have made predictions of the total demand for tourism talents from 2008 to 2015: growth rate of tourism talent demand over $9.6 \%$, while the growth rate of tourism employees does not exceed $7.1 \%$, that is to say, there's a huge

Supported by: "Empirical Studies on Correlation between Application-oriented Tourism Undergraduate Education and Graduates Employed in Tourism Industry in Jiangxi Province" (the Annual Project of 2016 of 13th Five-year Plan of Educational Science of Jiangxi Province, Grant No.16YB100) 
gap between supply and demand. As tourism is a laborintensive industry, it requires a lot of advanced and intermediate service staff and management staff who are welleducated and professional. Developing such a huge labor force with skills is the bounden duty of tourism professional education, and it brings a good opportunity for professional education development in tourism.

\section{PROBLEMS OF TALENTS DEVELOPMENT IN TOURISM INDUSTRY}

\section{A. Vague Direction in Tourism Talents Development}

This is a major problem in many tourism institutions in aspect of talents development. Colleges are not sure about what kind of qualifications dose the industry need; therefore, students are being guided in no clear directions or goals, leading to blindness in education. Many institutions spend much time on theoretical lectures in teaching, while pay little attention to students' practical abilities and skills training. Hence the students only master the theoretical knowledge but don't have the practical skills or flexible applying abilities. Rigid and mechanical mode of education leads to a group of graduates lacking of practical skills, and are unable to meet the actual requirements of tourism enterprises, causing an embarrassing fact that students are facing unemployment just after graduation, indirectly affecting the admissions of tourism colleges, making tourism talents development face severe test.

\section{B. Serious Gap between Tourism Market Demands and Tourism Talents Development}

Graduates are difficult to find a job after graduation, while employers are struggling to recruit good employees. This bicontradiction reflects a serious gap between talent development and market demands. China's tourism industry is facing serious problems such as lack of professionals, enterprises not having proper job placement, which is resulted from the dislocation between theory and practice in education. The demands for application-oriented tourism professionals are great nowadays, but tourism colleges mostly cultivate knowledge-based talents in tourism management and tourism theoretical study. They overemphasize theoretical knowledge in teaching, and basically ignore the development and training of practical application skills. This training model of tourism institutions does not consider dialectical unity linkages between market demands and personnel training objectives. The lack of exchange and cooperation between colleges and tourism industries results in the separation of colleges and enterprises. On the one hand, tourism companies do not care about college education, let alone participate in education, do not understand the methods and processes colleges developing talents. They recruit talents passively. On the other hand, colleges does not care about talents demand for industries and enterprises, do not know what kind of talents do enterprises need, use backward talent training model, and develop talents that are out of touch with the actual needs of the industry. These caused a serious gap between tourism talent development and tourism market demand.

\section{Rigid Mode for Cultivating Tourism Talents}

In recent years, with the enlarging development scale of tourism and growing demand for talents, the tourism education that is responsible for cultivating talents also develops rapidly. Due to this social trend, an increasing number of universities offer the tourism specialty. However, the general teaching system has many problems, such as the remained traditional concepts that tourism belongs to the service industry so the educational aim is cultivating service-oriented personnel; few devotions to related facilities in the specialty construction. At the same time, lack of professional teachers makes the comprehensive and systematic theories and skills education impossible, and emphasis on theory without practice in the teaching method and inefficient use of modern multi-media tools such as projection and slides hinder talents fostering severely. Therefore, due to market demands of tourism and existing problems, the reformation in the process of tourism talents cultivation gets necessary and extremely urgent.

\section{Severely in Need of Double-qualified Teachers}

Nowadays, higher education institutions are short of double-qualified teachers in developing tourism major. Many quinquagenarians switched to be halfway teachers, who had neither standard and systematic professional tourism knowledge nor practical experience working on tourism administration and economic management. Though graduating with a tourism major degree, most young teachers have few chances to practice because of the traditional concept of "elite education" that emphasizes theory without practice. Consequently, the young teachers are also far from being called double-qualified teachers for their insufficient working experiences and practical abilities.

\section{THE MAIN MODE OF TOURISM TALENTS CULTIVATION IN FOREIGN COUNTRIES}

\section{A. The "Cornell" Mode in USA}

The United States of America is a major tourism country in the world and a country with developed tourism education, which is a typical country of tourism talent cultivation and education. Tourism education in the United States began in the early 20th century, marked by the establishment of School of Hotel Management in Cornell University. As the only tourism school in The Ivy League of America, Cornell University is famous for its unique talent cultivation, and has cultivated many senior managers for the international hospitality industry. Cornell not only offers courses in economics, management, law, psychology, accounting, finance and other fields, but also pays attention to students' practice, requiring students to spend 800 hours on practice within two semesters. The school has its own hotel, the management of which is given to the students aiming to let students practice operation ability. The school's teaching staff is also very powerful who owns not only diploma, but also the corresponding vocational qualifications. 


\section{B. The "Dual System" Mode in German}

The tourism vocational education curriculum system in German consists of two parts. From the market demand, tourism vocational education (such as hotel and catering technical schools, etc.) is related to the dissemination of vocational skills, and tourism vocational academic education (such as comprehensive universities, applied universities and cooperative education colleges, etc.) is related to the dissemination of subject skills. The Dual System means that training takes place in the vocational schools funded by enterprises and the country. And the education mode focuses on enterprise training, and the practice in enterprises and theoretical teaching in vocational schools are closely combined, highlighting cultivation of students' ability of taking up an occupation and operation. The length of schooling is generally two to three and a half years. The teaching takes place in enterprises and school alternately, and about $60 \%-70 \%$ of the time in enterprises and $30 \%-40 \%$ in school.

In the forms of training organization, enterprises take the responsibility of training of practical operation and school completes the corresponding training of theoretical knowledge. Professional theory teaching and vocational skills training in enterprises are respectively guided by teachers of professional theory and teachers of enterprises training, which is conducive to play its advantages. The teachers taking practice teaching in enterprises is rich in practical experiences who are better at training vocational skills, while professional theory teachers are better at imparting professional theoretical knowledge.

\section{The "TAFE" Mode in Australia}

TAFE, technical and further education, is led by Australian government, mainly providing vocational education training. Australia has more than 270 TAFE colleges, which are directly run and managed by government. Based on the concept of lifelong vocational education, TAFE is an education system to solve a series of problems such as the interface between the school talent training and job market. The distinctive vocational education system lays a solid foundation for cultivating talents with the ability of practical work in all walks of life. TAFE system is characterized by the acceptance of students at all ages and different levels. Students can take part in learning, reflecting the concept of lifelong learning. Inservice staff, unemployed persons and graduates who have obtained a bachelor's degree or a master's degree also can choose to receive retraining from TAFE.

TAFE has always adopted four education modes: virtual internship company, project teaching, school-enterprise cooperation and industry training. This mode has greatly improved the practical ability of students, and has a unique school-running philosophy in curriculum setting, schoolenterprise cooperation and talent training, aiming to improve the quality of students.

\section{The "Government-Industry-University" Mode in Japan}

"Government-Industry-University Cooperation" in Japan refers to the cooperation between educational research institutions such as universities and industry. Meanwhile, the government and local public organizations provide institutional and budgetary financial support to achieve the goal of research and development of new technologies and creation of new industries. In 2006, the Japanese government revised Basic Law for Education, positioning "Government-IndustryUniversity Cooperation" as the second largest mission after "student education". Various circles in Japan have conducted extensive academic research and practical exploration on how to innovate cooperation mode and promote cooperation between vocational education subjects and other relevant subjects. Japan's "Government-Industry-University Cooperation" mode combines the basic knowledge education in schools with the intensive skills training in enterprises, and emphasizes the cultivation of students into comprehensive talents. The government promotes school-enterprise cooperation, and the training funds shall be jointly borne by the state, local government and enterprises. The university-owned enterprises provide good conditions and opportunities for students to practice.

\section{CREATIVE Thoughts ABOUT IMPROVING QuALITIES OF TOURISM TALENTS}

\section{A. Set Up Talents Training Concept}

The higher education should transform the sole subject "teachers' teaching" to binary subjects "teachers' teaching and students' learning" in order to build up the educational philosophy centering on current development needs and personnel market demands--the personnel training concept. Talent cultivation in the higher education must integrate with the market where people are tested finally. To solve the problem radically, it is essential to shift the educational mode from quantity-focus to quality-focus, get the undergraduate education subdivided, chosen and positioned, and educate research-based and skill-based human resource respectively. In the course of education, attach importance to students' coordinate development, that is, pay equal attention to science and the humanities, balance the universality with individuality, combine theory with practice, and consider the utility and morality.

\section{B. Foster High-quality Research-oriented and Application- oriented Workforce of Tourism}

In developed western countries, the education reform, after the popularization of higher education, focuses on the theme-how to improve talents quality. The main problem of higher education in our country has changed from the number of personnel to the quality. Talents fostered by higher education are normally classified as academic research ones and skills application ones according to international standard, both of which cannot exchange their talent quality evaluation system and standard. From the perspective of social diversity demand, talents development must be diversified. If the evaluation criterion of high quality is limited to the level of academic research, the talents structure will be imbalanced. Therefore, to 
meet the market diversity demand, colleges should evaluate personnel training by the standard as follows: if the feature is distinctive, if the students have their own specialties and can adapt to market requirement. High-quality talents conforming to times development are mainly classified as 2 categories: one is research-oriented talents who master advanced technology and core competence in the humanistic society; the other one is application-oriented person who acquires the market competition ability.

\section{Transform Teaching Methods}

In an era of Information Economy, the development of knowledge has 2 characteristics: large amounts of knowledge and quick renewal of information. Faced with the reality, the teaching should play a leading role in education as far as possible. It is necessary to improve students' ability to acquire knowledge by using modern information tools, but more significant is to give full play to the initiative of students' realizing how to learn with learning methods to compare and choose, strive to internalize the most basic and important knowledge as psychological quality of students, and strengthen the quality and skills. The cultivation goal can be changed from imparting knowledge into teaching students how to learn and obtaining the ability. This is the urgent requirement of the market economy and the times development as well as the inevitable choice of university.

\section{Reform Professional Courses}

Based on market demand, the tourism colleges and universities are mainly training high skilled applicable tourism professionals for the society, so if the teaching plan and professional courses are reasonable, conforming to social development needs have a close relationship with whether cultivated students meet the talents requirements of tourism enterprises and realize their self-worth. It has a deep understanding of social development and tourism's specific requirements on talents in cultural quality, knowledge system, ideology, the technical ability, etc, tourism colleges can conduct the fundamental reform in such aspects as curriculum, teaching methods according to their own school-running strength and characteristics.

As a result, with the attitude of serving for the society and being responsible for students, tourism colleges should analyze and study tourism human resources development according to the market demands, formulate a clear training plan, and set up a scientific and reasonable teaching plan, unifying the talent cultivation specifications and the actual demand of tourism. In professional settings, colleges should set up the specialty courses in view of tourism demands for applied and skilled talents, reflecting the successful docking between professional courses structure and the social demands.

\section{E. Transform the Standard of Education Evaluation System}

To cultivate high-quality talents and set up the system of cultivating high-quality talents, is about to transform the concentration of education evaluation system from basic knowledge examination to application ability examination. The education evaluation system, as the standard of teaching management, plays an important guiding role in teaching methods. Cultivating high-quality innovative talents, should take active thinking, applicable knowledge and innovation as the fundamental standards of teaching quality evaluation. The evaluation system focusing on application capabilities would help teachers transform education concept and teaching methods, and guide students to actively accept the learning method of ability fostering. Besides, this system requires teachers to view students' understanding of the subject and ability to solve practical problems as the standard, reduce rote knowledge examination questions, add examination questions that need thinking, analysis, discussion, independent personal opinions, and practical ability.

\section{CONCLUSION}

In recent years, with the continuous progress of Supply-side Reform, the structure of tourism industry has been constantly adjusted and optimized, and its integration with other industries has become closer. The country puts forward new requirements for tourism industry, and the tourism industry also puts forward requirements for practitioners, which requires them to constantly improve their comprehensive qualities. The cultivation of tourism management professionals should not only pay attention to the teaching of theoretical knowledge, but also the improvement of practical ability. In the future, the tourism industry should be closely linked with market demands continue to draw effective experiences, put forward practical measures, really do in accordance with students' aptitude to train high-quality practitioners.

\section{REFERENCES}

[1] Abraham Pizam. The State of Travel and Tourism Human Resources in Latin America. Tourism Management, 1999, 20:575-586

[2] Diyah Ernawati. Tourism Education at the Tertiary Level in Indonesia: An Exploratory Study. International Journal of Tourism Research 2002(04):145-150

[3] Huang Yi, Zhang Yu, Zhang Qun. Practical Teaching Modes and Experiences of Tourism Management Major in Foreign Higher Education [J]. Journal of Hunan Institute of Engineering (Social Science Edition), 2017(04): 78-82

[4] Yang Dong. On Tourism Education and Countermeasures for Cultivation of High-quality Tourism Professionals [J]. Journal of Puer University, 2019(03): 115-116.

[5] Zhang Sumei. Current Situation Analysis and Countermeasures of Tourism Education in China in Context of All-for-one Tourism [J]. College Education, 2016(12): 64-65.

[6] Luo Jinhua, Shi Yu. On Optimization of Cultivation System for Applied Talents Majored in Tourism Management [J]. Journal of Changchun Normal University, 2019(02): 126-131.

[7] Yuan Han. On Integration of Local Tourism Industry Development and Higher Vocational Tourism Education [J]. Journal of Kaifeng Institute of Education, 2017(11): 124-125.

[8] Li Yangbing. Discussion on Talent Cultivation Reform of Tourism Management Major in Application-oriented Universities [J]. The Guide of Science \& Education, 2018(11):63-64+66.

[9] Liu Lin. On Impact of the Talent Cultivation Mode of School-enterprise cooperation on Local Tourism Industry Development [J]. Tourism Overview, 2017(09): 40

[10] Li Yingce. On Demands for Tourism Talents and Development of Tourism Education [J]. Tourism Overview, 2014(06): 170-172. 